\title{
MicroRNA expression profiles in non-epithelial ovarian tumors
}

\author{
ROGER K. CHANG ${ }^{1}$, XIDAN LI $^{2}$, NINNI MU ${ }^{1}$, OLGA HRYDZIUSZKO ${ }^{3}$, BEATRIZ GARCIA-MAJANO ${ }^{1}$, \\ CATHARINA LARSSON ${ }^{1}$ and WENG-ONN LUI ${ }^{1}$ \\ ${ }^{1}$ Department of Oncology-Pathology, Karolinska Institutet, Cancer Center Karolinska, Karolinska University Hospital, \\ SE-171 76 Stockholm; ${ }^{2}$ Department of Medicine, Karolinska Institutet, SE-141 86 Huddinge; \\ ${ }^{3}$ National Bioinformatics Infrastructure Sweden, Science for Life Laboratory, SE-751 24 Uppsala, Sweden
}

Received July 10, 2017; Accepted September 28, 2017

DOI: 10.3892/ijo.2017.4200

\begin{abstract}
Ovarian germ cell tumors (OGCTs) and sex cord stromal tumors (SCSTs) are rare gynecologic tumors that are derived from germ and stromal cells, respectively. Unlike their epithelial counterparts, molecular pathogenesis of these tumor types is still poorly understood. Here, we characterized microRNA (miRNA) expression profiles of 9 OGCTs (2 malignant and 7 benign) and 3 SCSTs using small RNA sequencing. We observed significant miRNA expression variations among the three tumor groups. To further demonstrate the biological relevance of our findings, we selected 12 miRNAs for validation in an extended cohort of 16 OGCTs ( 9 benign and 7 malignant) and 7 SCSTs by reverse transcription-quantitative polymerase chain reaction. Higher expression of $m i R-373-3 p, m i R-372-3 p$ and $m i R-302 c-3 p$ and lower expression of $m i R-199 a-5 p, m i R-214-5 p$ and $m i R-202-3 p$ were reproducibly observed in malignant OGCTs as compared to benign OGCTs or SCSTs. Comparing with benign OGCTs, $m i R-202 c-3 p$ and $m i R-513 c-5 p$ were more abundant in SCSTs. Additionally, we examined Beclin 1 (BECN1), a target of $m i R-199 a-5 p$, in the clinical samples using western blot analysis. Our results show that BECN1 expression was higher in malignant OGCTs than benign OGCTs, which is concordant with their lower miR-199a-5p expression. This study suggests that these miRNAs may have potential value as tumor markers and implications for further understanding the molecular basis of these tumor types.
\end{abstract}

\section{Introduction}

Ovarian tumors are common with $>200,000$ women estimated to be diagnosed with ovarian cancer annually worldwide (1).

Correspondence to: Mr. Roger K. Chang or Dr Weng-Onn Lui, Department of Oncology-Pathology, Karolinska Institutet, Karolinska University Hospital-Solna, R8:04, SE-171 76 Stockholm, Sweden

E-mail: roger.chang@ki.se

E-mail: weng-onn.lui@ki.se

Key words: microRNAs, small RNA sequencing, ovarian germ cell tumors, sex cord stromal tumors, classification
Three main types are recognized according to the type of cell origin. Epithelial cancer is the most common form seen in the vast majority of cases. Germ cell tumors (GCTs) develop in the egg cells (oocytes) of ovary. Stromal cell tumors, arise from cells involved in ovarian steroid production (e.g., granulosa, theca and Leydig cells) (2).

Although non-epithelial ovarian tumors are uncommon, they are histologically, genetically and clinically heterogeneous causing major challenges for treatment and clinical workup. Ovarian GCTs (OGCTs) typically affect young women ( $<30$ years) (3). It is further subclassified based on histology and clinical behavior as: mature teratoma which is benign, and the malignant form immature teratomas and malignant OGCTs (including dysgerminoma, yolk sac tumor, embryonal carcinoma, choriocarcinoma and mixed GCT). Mature teratoma, which is the most common among all OGCTs, may contain a variety of well-differentiated tissues, such as hair, fat, teeth and bone. In rare cases, complex organs such as brain matter, eyes, torso, hands, feet and other limbs are formed in teratomas (4-7). Immature teratomas, on the other hand, contain incompletely differentiated tissues in addition to mature elements, and have worse prognosis (8). Malignant OGCTs are thought to arise from the pluripotent primordial germ cells, which can differentiate into various histologies. While dysgerminoma is composed of primitive undifferentiated germ cells, the other malignant OGCTs (non-dysgerminomas) are categorized based on the degree of differentiation from their precursor cells that mimic embryonic and extra-embryonic tissues (3).

Patients with sex cord stromal tumor (SCST) can display various hormone-mediated syndromes and a variety of clinical features depending on their cellular origin. Tumors derived from ovarian cells (such as granulosa and theca cells) usually exhibit clinical features associated with excessive production of estrogen, while those derived from Sertoli and Leydig cells exhibit phenotypes resulting from elevated levels of androgens. The prognosis of SCST is generally good, although a minority of patients develop metastasis (9).

The molecular basis underlying the non-epithelial ovarian tumors is still poorly understood. However, accumulating evidence indicate that both OGCTs and SCSTs may reflect the developmental changes of the germ and stromal cells in the ovary. For OGCTs, it is clear that most of the malignant tumors express pluripotency markers. They generally express high level 
of POU class 5 homeobox 1 (POU5F1), v-KIT proto-oncogene receptor tyrosine kinase (KIT), Lin-28 homolog A (LIN28A) and Nanog homeobox (NANOG) $(10,11)$. On the other hand, the benign tumors (mature teratomas) have complex expression patterns due to the cell composition of multiple cell types in different tumors (2).

For SCSTs, they express transcription factors that play important roles in sex determination, e.g., granulosa cell tumors express Forkhead box L2 (FOXL2) and Sertoli-Leydig cell tumors express sex determining region Y box 9 (SOX9), which controls ovary and testis determination, respectively. The majority (97\%) of ovarian adult granulosa cell tumors harbor somatic FOXL2 mutations (12), which promote granulosa cell survival (13) and tumorigenesis (14). On the other hand, somatic missense mutations of Dicer 1 ribonuclease III (DICER 1$)$ are found in $60 \%$ of the ovarian Sertoli-Leydig cell tumors (15). DICER1 plays an important role in microRNA (miRNA) processing. Its mutations in SCSTs cause selective processing of 3'-strand miRNAs (15). However, how these mutations result in sex cell fate decision or tumorigenesis remain unknown.

miRNAs are single-stranded RNAs of 22 nucleotides in length, which regulate gene expression in many biological processes, including cell growth, differentiation and tumorigenesis (16). Distinct miRNA expression profiles have been identified in a variety of tumor types associated with histological subtypes and patient outcome, suggesting their potential use as biomarkers for diagnosis and prognosis (17). miRNA expression profiles have been investigated in some ovarian germ cell tumors. However, in all studies, the OGCTs were combined with their testicular counterparts for analysis (18-21). One of the reasons may due to the rarity of these tumor types and very few samples were analyzed. Although DICERI is frequently mutated in SCSTs (15), miRNA expression profiles of this tumor type and how their expression profiles relate to OGCTs are yet to be investigated.

In this study, we characterized miRNA profiles of OGCTs and SCSTs using small RNA (sRNA) sequencing, and compared the expression differences between malignant and benign OGCTs, as well as between SCSTs and OGCTs. We identified miRNA expression patterns associated with different tumor types, suggesting their potential use as a tool for defining their histological and biological differences.

\section{Materials and methods}

Clinical samples. This study included 23 frozen non-epithelial ovarian tumors, consisting of 16 ovarian germ cell tumors (OGCT1-16) and 7 sex cord stromal tumors (SCST1-7). The age at diagnosis and the histological type of each tumor are given in Table I. All tumors were provided by the Cooperative Human Tissue Network, which is funded by the National Cancer Institute, USA. Other investigators may have received specimens from the same subjects. The study was approved by the Stanford Human Subjects Review Committee. All clinical samples were de-identified, therefore no written informed consent was required.

RNA isolation and quantification. mirVana miRNA isolation kit (Thermo Fisher Scientific, Waltham, MA, USA) was used to extract sRNA and total RNA for cloning and reverse transcription-quantitative polymerase chain reaction (RT-qPCR) analysis, respectively. RNA concentrations were determined by the NanoDrop ND-1000 spectrophotometer (NanoDrop Technologies, Wilmington, DE, USA).

sRNA library construction and sequencing. sRNA cloning was performed on 9 OGCTs ( 7 benign and 2 malignant) and 3 SCSTs, using previously described methodologies (22). Briefly, sRNAs were ligated with adenylated 3'-adaptor and purified on $12 \%$ denaturing polyacrylamide gel. Second ligation reaction was performed with 5'-adaptor, followed by gel purification. Complementary DNA (cDNA) synthesis was performed using the reverse transcription enzyme SuperScript II (Thermo Fisher Scientific) together with the reverse transcription primer. cDNA was then PCR amplified for 16-20 cycles with forward and reverse primers. sRNAsequencing libraries were sequenced by Solexa/Illumina sequencing platform (Illumina $1 \mathrm{G}$ Genome Analyzer; Illumina Inc., San Diego, CA, USA). The sequence of the adaptors and primers has been described previously (22). The sequencing data are available at Gene Expression Omnibus (accession no. GSE98536).

miRNA analysis. sRNA sequencing reads from each of the pooled libraries were separated based on their barcode sequence. Adaptor sequences were trimmed and filtered using the package Fastx-toolkit. The resulting dataset was aligned to miRBase database version 21 (http://www.mirbase. org/) for mature miRNA using Bowtie short read aligner version 1.1.1 (23) with settings -f -n 0 -1 15 -k 200 -S -best -chunkmbs 128. All aligned reads were sorted and indexed by SAMtools version 1.1 (24). For miRNA quantification, the script HTSeq-count of the HTSeq version 0.6.1 was used (25). For clustering analysis, the miRNA counts were normalized by TMM (trimmed mean method) (26) and the normalized expression values were clustered based on Euclidean distance. For identification of differentially expressed miRNAs between two groups, the miRNA counts were normalized and analyzed by DESeq2 using default settings (27).

TaqMan RT-qPCR. RT-qPCR was performed to quantify the expression levels of $m i R-373-3 p, m i R-372-3 p, m i R-302 c-3 p$, miR-199a-5p, miR-125a-5p, miR-21, miR-34a, miR-202-5p, $m i R-513 c-5 p, m i R-193 a-3 p, m i R-214-5 p$ and let-7f, using TaqMan miRNA assays (Thermo Fisher Scientific). Approximately $120 \mathrm{ng}$ of total RNA was reversed transcribed using the High-Capacity cDNA Reverse Transcription kit (Thermo Fisher Scientific). The synthesized cDNA was then diluted 2- to 10-fold prior to RT-qPCR with TaqMan Universal PCR Master Mix without AmpErase UNG (Thermo Fisher Scientific). The amplification was performed using the Applied Biosystems 7500 Fast Real-time PCR system (Thermo Fisher Scientific) with the following conditions: an initial denaturation at $95^{\circ} \mathrm{C}$ for $10 \mathrm{~min}, 40$ step cycles of denaturing at $95^{\circ} \mathrm{C}$ for $15 \mathrm{sec}$ and annealing at $60^{\circ} \mathrm{C}$ for $60 \mathrm{sec}$. Each reaction was performed in triplicate. The average $\mathrm{Ct}$-value of each analyzed miRNA was normalized to $R N U 6 B$, and reported as $2^{-\Delta \mathrm{CT}}$. RNU6B was chosen as an endogenous control due to its stability in the samples analyzed (standard deviation of average $\mathrm{Ct}=1.8$; data not shown). 
Table I. Non-epithelial ovarian tumors included in the study.

\begin{tabular}{|c|c|c|c|c|c|c|}
\hline \multirow[b]{2}{*}{ Sample no. } & \multirow[b]{2}{*}{ Age at diagnosis (year) } & \multicolumn{3}{|c|}{ Tumor classification } & \multicolumn{2}{|c|}{ Analysed by } \\
\hline & & Diagnosis & Subclassification & Type & sRNA seq & RT-qPCR \\
\hline OGCT1 & 19 & OGCT & Dysgerminoma & Malignant & - & RT-qPCR \\
\hline OGCT2 & 21 & OGCT & Dysgerminoma & Malignant & - & RT-qPCR \\
\hline OGCT3 & 41 & OGCT & Dysgerminoma & Malignant & - & RT-qPCR \\
\hline OGCT4 & 73 & OGCT & Dysgerminoma & Malignant & sRNA seq & RT-qPCR \\
\hline OGCT5 & 24 & OGCT & Yolk sac tumor & Malignant & - & RT-qPCR \\
\hline OGCT6 & 17 & OGCT & Yolk sac tumor & Malignant & - & RT-qPCR \\
\hline OGCT7 & 28 & OGCT & Primitive germ cell tumor & Malignant & sRNA seq & RT-qPCR \\
\hline OGCT8 & 26 & OGCT & Mature teratoma & Benign & sRNA seq & RT-qPCR \\
\hline OGCT9 & 64 & OGCT & Mature teratoma & Benign & sRNA seq & RT-qPCR \\
\hline OGCT10 & 47 & OGCT & Mature teratoma & Benign & sRNA seq & RT-qPCR \\
\hline OGCT11 & 58 & OGCT & Mature teratoma & Benign & - & RT-qPCR \\
\hline OGCT12 & 77 & OGCT & Mature teratoma & Benign & sRNA seq & RT-qPCR \\
\hline OGCT13 & 47 & OGCT & Mature teratoma & Benign & sRNA seq & RT-qPCR \\
\hline OGCT14 & 51 & OGCT & Mature teratoma & Benign & sRNA seq & RT-qPCR \\
\hline OGCT15 & 54 & OGCT & Mature teratoma & Benign & sRNA seq & RT-qPCR \\
\hline OGCT16 & 18 & OGCT & Mature teratoma & Benign & - & RT-qPCR \\
\hline SCST1 & 84 & SCST & Signet ring-stromal tumor & Benign & sRNA seq & RT-qPCR \\
\hline SCST2 & 45 & SCST & Fibrothecoma & Benign & sRNA seq & RT-qPCR \\
\hline SCST3 & 46 & SCST & Sex cord stromal tumor & Malignant & sRNA seq & RT-qPCR \\
\hline SCST4 & 15 & SCST & Granulosa cell tumor & Malignant & - & RT-qPCR \\
\hline SCST5 & 48 & SCST & Granulosa cell tumor & Malignant & - & RT-qPCR \\
\hline SCST6 & 15 & SCST & Sertoli leydig cell tumor & Malignant & - & RT-qPCR \\
\hline SCST7 & 20 & SCST & Granulosa cell tumor & Malignant & - & RT-qPCR \\
\hline
\end{tabular}

No., number; OGCT, ovarian germ cell tumor; SCST, sex cord stromal tumor; sRNA seq, small RNA sequencing; RT-qPCR, reverse transcription-quantitative polymerase chain reaction.

Western blotting. Western blotting was performed on 7 SCSTs, 9 benign and 7 malignant OGCTs. Total protein lysates were prepared using NP-40 lysis buffer (Thermo Fisher Scientific) with addition of $1 \mathrm{mM}$ phenylmethanesulfonyl (Sigma-Aldrich, St. Louis, MQ, USA) and protease inhibitor (complete protease inhibitor cocktail; Sigma-Aldrich). The concentrations were measured using the Pierce BCA Protein assay kit (Thermo Fisher Scientific). Protein lysates of $30 \mu \mathrm{g}$ were separated in NuPAGE Novex 4-12\% Bis-Tris gel and transferred to nitrocellulose membranes. The membranes were blocked with 5\% skim milk diluted in Tris-buffered saline/0.05\% Tween-20 prior to incubation with anti-BECN1 rabbit polyclonal (Novus Biologicals; dilution 1:1,000) or anti-GAPDH rabbit monoclonal (Cell Signaling Technology; dilution at $1: 1,000)$ antibodies overnight at $4^{\circ} \mathrm{C}$. Anti-rabbit IgG-HRP (Cell Signaling Technology; dilution at 1:2,000) was used as a secondary antibody. Signals were detected using the Novex ECL HRP chemiluminescent substrate reagent (Thermo Fisher Scientific) and LI-COR Odyssey Fc Imaging system (LI-COR Biosciences, Lincoln, NE, USA) and quantified using Image Studio Lite version 5.2 (LI-COR Biosciences).
Statistical analysis. All statistical tests were performed using Statistical Package for the Social Sciences (SPSS) version 24 (IBM, Armonk, NY, USA), unless specified otherwise. Kruskal-Wallis test was used for comparisons among three sample groups, and Mann-Whitney U test was used for two groups. A difference of $\mathrm{P}<0.05$ was considered to indicate a statistically significant difference.

\section{Results}

miRNA expression profiles in non-epithelial ovarian tumors by sRNA sequencing. To assess the miRNA profiles of non-epithelial ovarian tumors, we performed sRNA sequencing of 9 OGCTs and 3 SCSTs. In total, we obtained 2,949,836 reads for OGCTs (benign, 919,886; malignant, 2,029,950) and $1,198,120$ reads for SCSTs. On average, 213,678 reads from the malignant OGCT libraries, 259,915 reads from the benign OGCT libraries and 262,386 reads from the SCST libraries were mapped to mature miRNAs from miRBase release 21 .

To determine whether miRNA expression profiles were distinct among the three non-epithelial ovarian tumor groups, we performed unsupervised clustering of the samples and 
A

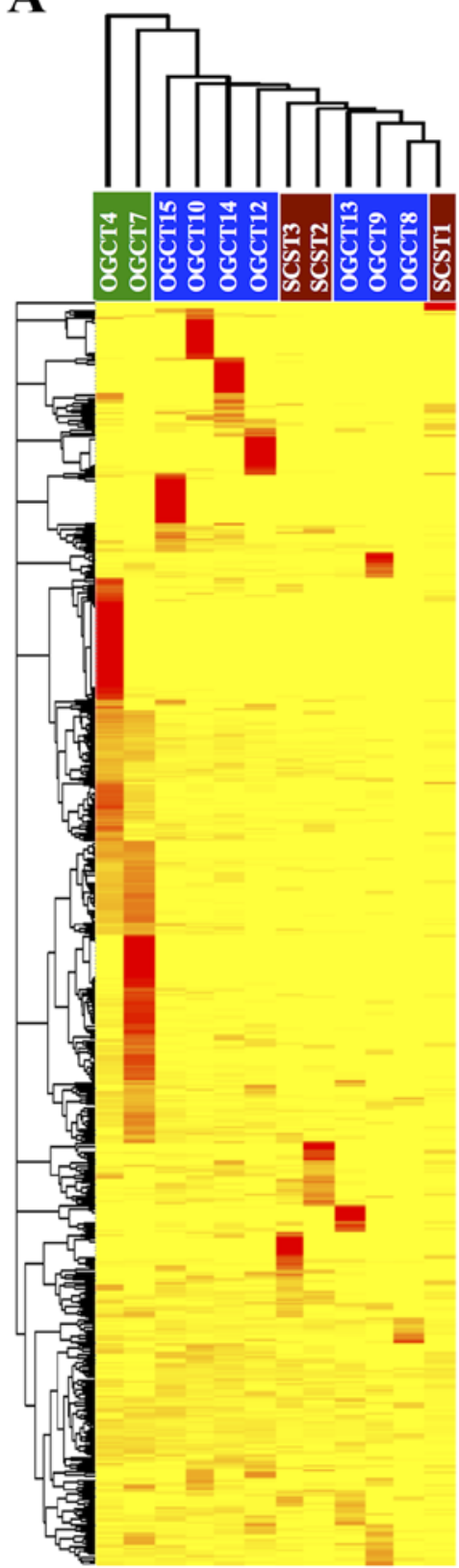

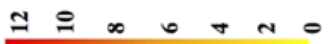

B

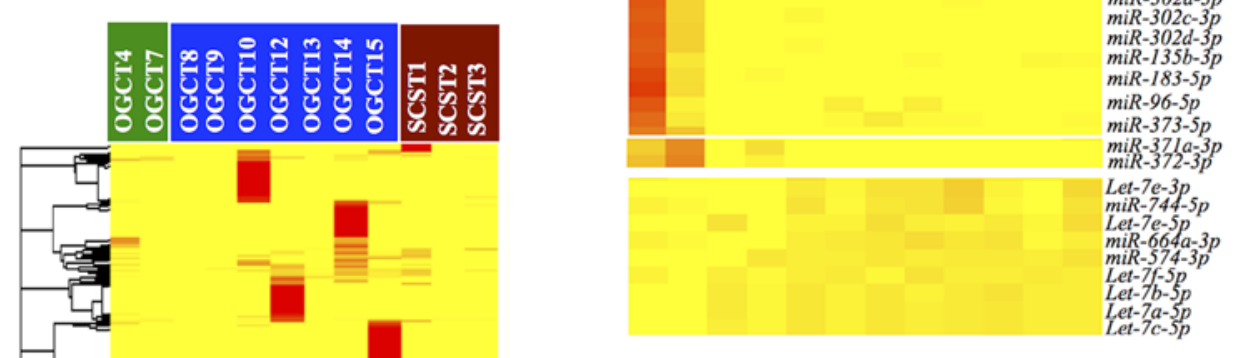

D

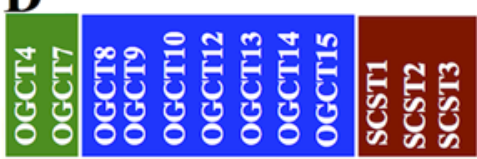

$m i R-193 b-5 p$ miR -451 I miR $-502-3 p$ $m i R-320$ $m i R-141-3 p$
$m i R-200 a-3 p$ $m i R-423-5 p$ miR $22-5 p$

E
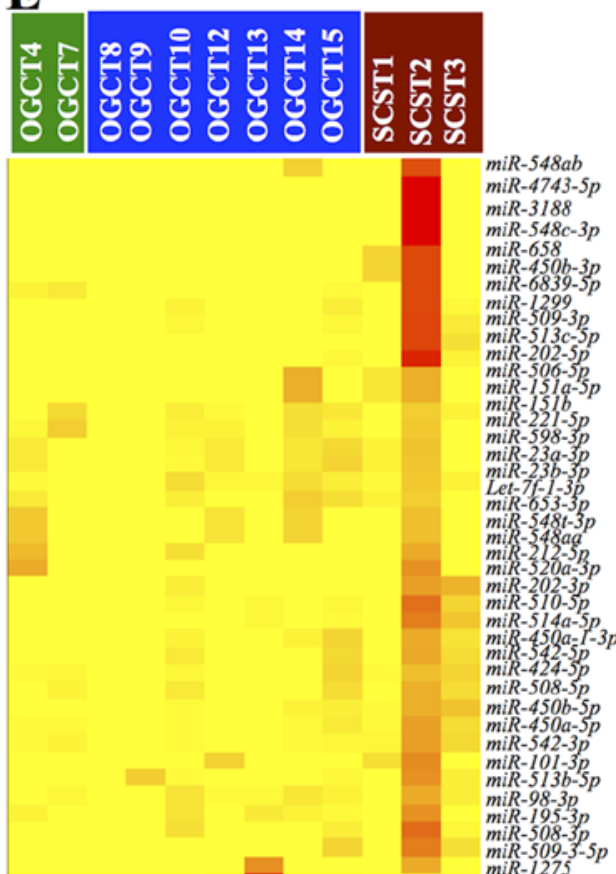

Figure 1. Clustering analysis of miRNA expression in 9 OGCTs (7 benign and 2 malignant) and 3 SCSTs. (A) Unsupervised clustering of the samples based on miRNA expression identified two major groups: one group with both malignant OGCTs and the other group consisted of both benign OGCTs and SCSTs. (B) Clustering of miRNA expression illustrates miRNA expression signatures associated with tumor types, which are further highlighted in (C-E). Clustered miRNA expression patterns associated with malignant OGCTs (C), benign OGCTs (D) and SCSTs (E). Each row represents the relative expression for a single miRNA and each column shows the expressions for a single sample. The red or yellow color indicates relatively high or low expression, respectively. OGCTs, ovarian germ cell tumors; SCSTs, sex cord stromal tumors.

miRNA expression based on Euclidean distance. As shown in the dendrogram in Fig. 1A, the benign OGCTs and SCSTs were closely related but separated from the two malignant OGCTs, suggesting distinct miRNA expression patterns in malignant 
A

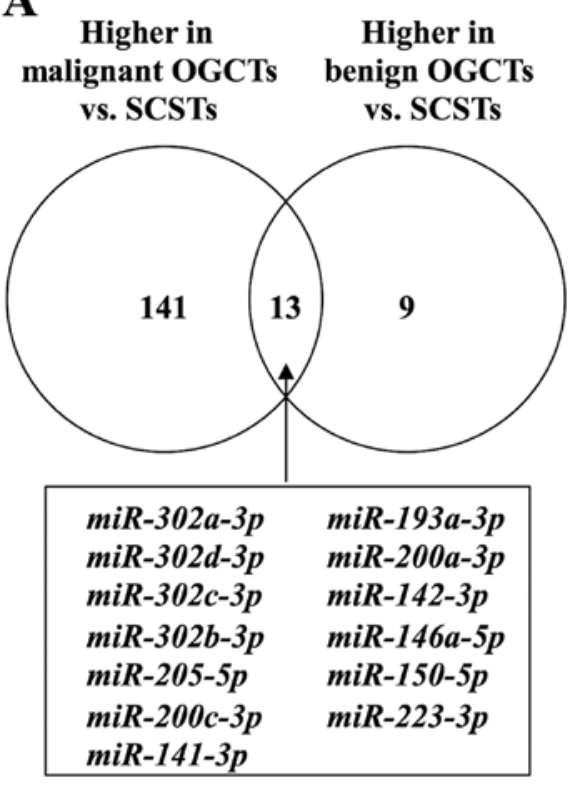

B

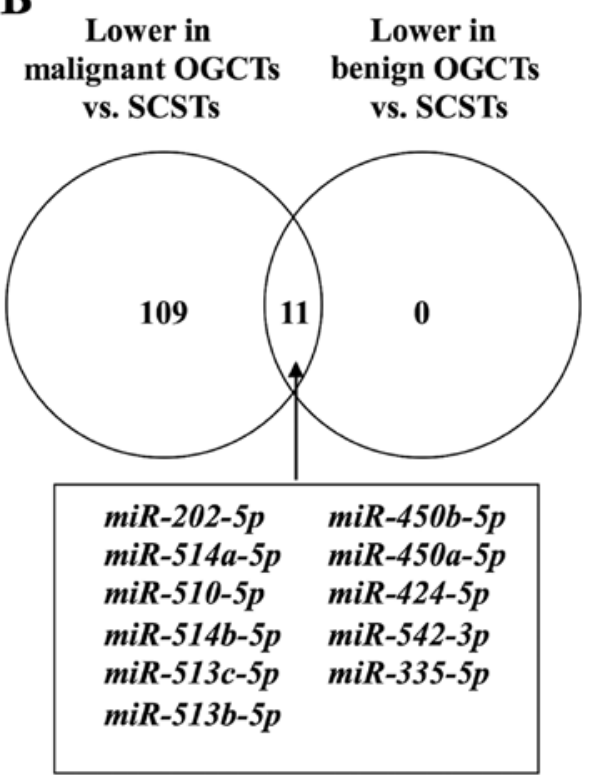

Figure 2. Venn diagrams illustrating the number of differentially expressed miRNAs between malignant and benign OGCTs as compared to SCSTs. (A) Number of miRNAs with higher expression. (B) Number of miRNAs with lower expression in the malignant or benign OGCTs. The common differentially expressed miRNAs are shown in the box, while the unique differentially expressed miRNAs for malignant or benign OGCTs are given in Table II. OGCTs, ovarian germ cell tumors; SCSTs, sex cord stromal tumors.

OGCTs and more similar miRNA expression profiles between benign OGCTs and SCSTs.

To illustrate whether specific miRNA expression signatures were distinct among these tumor groups, we performed hierarchical clustering of the miRNA expressions (Fig. 1B). Notably, several miRNAs were apparently unique to specific tumor types (Fig. 1C-E). For malignant OGCTs, several $m i R-548$ family, $m i R-302$ and $m i R-371 \sim 373$ clusters were more abundant, while several let-7 family members were lower than the benign OGCTs and SCSTs (Fig. 1C). For benign OGCTs, the miRNA expression patterns were not homogenous among the same tumor type (Fig. 1D). However, $m i R-193 b-5 p / 3 p$, $m i R-320 a / b$ and $m i R-22-5 p$ were frequently more abundant in the benign OGCTs as compared to the malignant OGCTs and SCSTs. Similarly, we also observed heterogeneous miRNA expression profiles among the three SCSTs. However, $m i R-202$ and $m i R-506 \sim 514$ cluster were higher in at least two SCSTs and absent or lower expression in the malignant and benign OGCTs (Fig. 1E).

Differentially expressed miRNAs among the three tumor types. We applied DESeq2 analysis to identify differentially expressed miRNAs between malignant and benign OGCTs. The analysis identified 128 and 59 miRNAs with higher and lower expression respectively, in the malignant OGCTs compared to the benign OGCTs (false discovery rate $<0.5$; data not shown). Notably, $m i R-302 \sim 367$ and $m i R-371 \sim 373$ clusters were among the differentially expressed miRNAs that had higher expression in the malignant tumors compared to the benign tumors. Additionally, expression of several let-7 family members was lower in the malignant than the benign OGCTs.

For comparison between malignant OGCTs and SCSTs, we identified 120 miRNAs with higher expression and
154 miRNAs with lower expression in the malignant OGCTs compared to SCSTs (data not shown). Among the differentially expressed miRNAs, lower expression of $m i R-202-5 p$, $m i R-506 \sim 514$ cluster and let-7 family, as well as higher expression of $m i R-302$ and $m i R-371 \sim 373$ cluster in the malignant OGCTs were also noted in the clustering data (Fig. $1 \mathrm{C}$ and E).

Strikingly, the number of differentially expressed miRNAs between SCSTs and benign OGCTs was much fewer, i.e., 11 miRNAs had lower expression and 22 had higher expression in the benign OGCTs than the SCSTs (data not shown). Notably, all 11 miRNAs with lower expression and 13 out of the 22 miRNAs with higher expression in the benign OGCTs were overlapped in both comparisons between SCSTs and malignant or benign OGCTs (Fig. 2), suggesting that these miRNAs may be specific for SCSTs. Comparing with SCSTs, 141 miRNAs with higher expression and 109 with lower expression were unique for malignant OGCTs, while only 9 miRNAs with higher expression were unique for benign OGCTs (Fig. 2 and Table II).

Validation of differentially expressed miRNAs by RT-qPCR. To validate the sRNA sequencing findings, we selected 12 miRNAs (i.e., $m i R-373-3 p, m i R-372-3 p, m i R-302 c-3 p$, miR-199a-5p, $m i R-125 a-5 p, m i R-21, m i R-34 a, m i R-202-5 p, m i R-513 c-5 p$, $m i R-193 a-3 p, m i R-214-5 p$ and let-7f) for RT-qPCR in an extended cohort of samples, which consisted of 16 OGCTs ( 9 benign and 7 malignant) and 7 SCSTs. These miRNAs were selected from different comparisons, and because of their involvement in testicular GCTs ( $m i R-373-3 p, m i R-372-3 p$, $m i R-302 c-3 p$, miR-21, miR-513c-5p, miR-199a-5p, miR-214-5p and let-7f) $(11,19,20,28-32)$ or other tumor types (miR-125a-5p, $m i R-34 a$, $m i R-193 a-3 p$ and $m i R-202-5 p)$ (33-35).

In the comparison between malignant and benign OGCTs, 8 of the 12 miRNAs were concordant between the sRNA 
Table II. Unique differentially expressed miRNAs in malignant and benign OGCT as compared to SCST.

Differentially expressed miRNAs compared to SCST

\begin{tabular}{|c|c|c|c|c|c|}
\hline \multicolumn{6}{|l|}{ Higher in malignant OGCT } \\
\hline$m i R-373-3 p$ & $m i R-376 b-3 p$ & $m i R-519 e-5 p$ & $m i R-520 c-3 p$ & $m i R-155-5 p$ & $m i R-148 a-3 p$ \\
\hline$m i R-372-3 p$ & $m i R-9-5 p$ & $m i R-654-3 p$ & $m i R-758-3 p$ & $m i R-544 a$ & $m i R-501-5 p$ \\
\hline$m i R-182-5 p$ & $m i R-377-3 p$ & $m i R-18 a-3 p$ & $\operatorname{miR}-1296-5 p$ & $m i R-190 a-5 p$ & $m i R-185-5 p$ \\
\hline$m i R-183-5 p$ & $m i R-363-3 p$ & $m i R-381-5 p$ & $m i R-519 c-3 p$ & $m i R-505-3 p$ & $m i R-15 b-5 p$ \\
\hline$m i R-767-3 p$ & $m i R-629-3 p$ & $m i R-183-3 p$ & $m i R-543$ & $m i R-93-3 p$ & $m i R-433-3 p$ \\
\hline$m i R-371 a-3 p$ & $m i R-18 a-5 p$ & $m i R-361-3 p$ & $m i R-494-3 p$ & $m i R-149-5 p$ & $m i R-15 a-5 p$ \\
\hline$m i R-302 b-5 p$ & $m i R-3180-3 p$ & $m i R-545-3 p$ & $m i R-146 b-5 p$ & $m i R-769-5 p$ & $m i R-339-3 p$ \\
\hline$m i R-7-5 p$ & $m i R-655-3 p$ & $m i R-345-5 p$ & $m i R-590-5 p$ & $m i R-20 a-5 p$ & $m i R-340-3 p$ \\
\hline$m i R-3529-3 p$ & $m i R-18 b-5 p$ & $m i R-1277-3 p$ & $m i R-409-3 p$ & $m i R-92 a-1-5 p$ & $m i R-93-5 p$ \\
\hline$m i R-96-5 p$ & $m i R-373-5 p$ & $m i R-1248$ & $m i R-154-5 p$ & $m i R-134-5 p$ & $m i R-378 a-5 p$ \\
\hline$m i R-767-5 p$ & $m i R-136-5 p$ & $m i R-652-5 p$ & $m i R-625-3 p$ & $m i R-487 b-3 p$ & $m i R-181 d-5 p$ \\
\hline$m i R-105-5 p$ & $m i R-5585-3 p$ & $m i R-210-3 p$ & $m i R-31-3 p$ & $m i R-30 e-5 p$ & $m i R-505-5 p$ \\
\hline$m i R-367-3 p$ & $m i R-493-3 p$ & $m i R-3679-5 p$ & $m i R-512-3 p$ & $m i R-16-2-3 p$ & $m i R-493-5 p$ \\
\hline$m i R-135 b-5 p$ & $m i R-372-5 p$ & $m i R-299-3 p$ & $m i R-377-5 p$ & $\operatorname{miR}-876-5 p$ & $m i R-130 b-3 p$ \\
\hline$m i R-380-3 p$ & $m i R-20 b-5 p$ & $m i R-339-5 p$ & $m i R-324-5 p$ & $m i R-651-5 p$ & $m i R-92 b-3 p$ \\
\hline$m i R-154-3 p$ & $m i R-376 a-5 p$ & $m i R-548 b-5 p$ & $m i R-30 d-5 p$ & $m i R-19 a-3 p$ & $m i R-16-5 p$ \\
\hline$m i R-539-3 p$ & $m i R-515-5 p$ & $m i R-382-5 p$ & $m i R-421$ & $m i R-127-5 p$ & $m i R-301 a-3 p$ \\
\hline$m i R-381-3 p$ & $m i R-548 d-5 p$ & $m i R-379-3 p$ & $m i R-519 b-3 p$ & $m i R-342-3 p$ & $m i R-374 a-5 p$ \\
\hline$m i R-425-5 p$ & $m i R-329-3 p$ & $m i R-517 a-3 p$ & $m i R-92 b-5 p$ & $m i R-485-5 p$ & $m i R-34 a-5 p$ \\
\hline$m i R-495-3 p$ & $m i R-181 c-5 p$ & $m i R-517 b-3 p$ & $m i R-187-3 p$ & $m i R-423-3 p$ & $m i R-21-5 p$ \\
\hline$m i R-302 a-5 p$ & $m i R-302 d-5 p$ & $m i R-103 a-3 p$ & $m i R-519 a-3 p$ & $m i R-550 a-3 p$ & $m i R-19 b-3 p$ \\
\hline$m i R-485-3 p$ & $\operatorname{miR}-548 y$ & $m i R-103 b$ & $m i R-337-3 p$ & $m i R-550 b-2-5 p$ & \\
\hline$m i R-9-3 p$ & $m i R-484$ & $m i R-107$ & $m i R-454-3 p$ & $m i R-3065-5 p$ & \\
\hline$m i R-409-5 p$ & $m i R-487 a-3 p$ & $m i R-1323$ & $m i R-941$ & $m i R-127-3 p$ & \\
\hline \multicolumn{6}{|l|}{ Lower in malignant OGCT } \\
\hline$m i R-206$ & let- $7 b-5 p$ & $m i R-199 a-3 p$ & $m i R-195-3 p$ & $m i R-200 b-3 p$ & $m i R-502-3 p$ \\
\hline$m i R-509-3 p$ & let $-7 c-5 p$ & $m i R-199 b-3 p$ & $m i R-30 c-1-3 p$ & $\operatorname{miR}-615-3 p$ & $m i R-125 a-5 p$ \\
\hline$m i R-508-3 p$ & let $-7 a-5 p$ & $m i R-1294$ & let-7f-5p & $m i R-199 b-5 p$ & $m i R-30 a-5 p$ \\
\hline$m i R-30 c-2-3 p$ & let-7d-3p & $m i R-98-3 p$ & $m i R-1299$ & $m i R-1270$ & $m i R-145-3 p$ \\
\hline$m i R-542-5 p$ & $m i R-574-3 p$ & $m i R-508-5 p$ & $m i R-135 a-5 p$ & $m i R-1180-3 p$ & $m i R-193 a-5 p$ \\
\hline$m i R-204-5 p$ & let-7f-2-3p & $m i R-214-5 p$ & $m i R-664 a-3 p$ & $m i R-744-5 p$ & $m i R-99 b-5 p$ \\
\hline$m i R-211-5 p$ & $m i R-874-5 p$ & $m i R-125 b-1-3 p$ & $m i R-1271-5 p$ & $m i R-365 a-3 p$ & $m i R-660-5 p$ \\
\hline$m i R-1269 a$ & $m i R-143-3 p$ & $m i R-99 a-5 p$ & $m i R-10 b-5 p$ & $m i R-365 b-3 p$ & $m i R-532-5 p$ \\
\hline$m i R-450 a-2-3 p$ & $m i R-133 a-5 p$ & $m i R-30 b-3 p$ & $m i R-95-3 p$ & $m i R-331-5 p$ & $m i R-29 b-2-5 p$ \\
\hline$m i R-506-5 p$ & let-7b-3p & $m i R-196 a-5 p$ & $m i R-196 b-5 p$ & $m i R-140-5 p$ & $m i R-181 a-5 p$ \\
\hline$m i R-483-5 p$ & $m i R-214-3 p$ & $m i R-30 a-3 p$ & $m i R-574-5 p$ & $m i R-26 a-5 p$ & $m i R-29 a-3 p$ \\
\hline let $-7 c-3 p$ & $m i R-675-5 p$ & $m i R-100-5 p$ & $m i R-23 a-3 p$ & let-7d-5p & $m i R-29 c-3 p$ \\
\hline$m i R-133 a-3 p$ & $m i R-1$ & $m i R-509-3-5 p$ & $m i R-23 b-3 p$ & $m i R-125 a-3 p$ & $m i R-30 b-5 p$ \\
\hline$m i R-375$ & $m i R-193 b-5 p$ & $m i R-30 e-3 p$ & $m i R-122-5 p$ & $m i R-191-5 p$ & $m i R-186-5 p$ \\
\hline$m i R-133 b$ & $m i R-125 b-5 p$ & $m i R-98-5 p$ & $m i R-664 a-5 p$ & $m i R-184$ & \\
\hline$m i R-135 a-3 p$ & $m i R-3609$ & $m i R-199 a-5 p$ & $m i R-539-5 p$ & $m i R-221-5 p$ & \\
\hline let- $7 e-5 p$ & $m i R-99 a-3 p$ & $m i R-532-3 p$ & $m i R-26 a-2-3 p$ & $m i R-423-5 p$ & \\
\hline$m i R-4500$ & let-7f-1-3p & $m i R-30 d-3 p$ & $m i R-32-3 p$ & $m i R-3184-3 p$ & \\
\hline$m i R-450 a-1-3 p$ & let-7e-3p & $m i R-708-3 p$ & $m i R-28-3 p$ & $m i R-1306-5 p$ & \\
\hline \multicolumn{6}{|l|}{ Higher in benign OGCT } \\
\hline$m i R-1247-5 p$ & $m i R-203 a$ & $m i R-338-3 p$ & $m i R-145-5 p$ & $m i R-10 a-5 p$ & $m i R-22-3 p$ \\
\hline$m i R-199 b-5 p$ & $m i R-320 a$ & $m i R-320 b$ & & & \\
\hline
\end{tabular}


Table III. Evaluation of 12 selected miRNAs using sRNA sequencing and RT-qPCR methods.

\begin{tabular}{|c|c|c|c|c|c|c|c|c|c|}
\hline \multirow[b]{2}{*}{ miRNA } & \multicolumn{3}{|c|}{ Malignant vs. benign OGCTs ${ }^{a}$} & \multicolumn{3}{|c|}{ Malignant OGCTs vs. SCSTs ${ }^{\mathrm{b}}$} & \multicolumn{3}{|c|}{ Benign OGCTs vs. SCSTs ${ }^{\mathrm{b}}$} \\
\hline & sRNA seq & RT-qPCR & Concordance & sRNA seq & RT-qPCR & Concordance & sRNA seq & RT-qPCR & Concordance \\
\hline$m i R-372-3 p$ & Higher & Higher & Yes & Higher & Higher & Yes & Equal & Equal & Yes \\
\hline $\operatorname{miR}-373-3 p$ & Higher & Higher & Yes & Higher & Higher & Yes & Equal & Equal & Yes \\
\hline$m i R-302 c-3 p$ & Higher & Higher & Yes & Higher & Higher & Yes & Higher & Equal & No \\
\hline$m i R-199 a-5 p$ & Lower & Lower & Yes & Lower & Lower & Yes & Equal & Equal & Yes \\
\hline $\operatorname{miR}-214-5 p$ & Lower & Lower & Yes & Lower & Lower & Yes & Equal & Equal & Yes \\
\hline$m i R-202-3 p$ & Lower & Lower & Yes & Lower & Lower & Yes & Lower & Lower & Yes \\
\hline$m i R-513 c-5 p$ & Equal & Lower & No & Lower & Lower & Yes & Lower & Lower & Yes \\
\hline let-7f & Lower & Equal & No & Lower & Equal & No & Equal & Equal & Yes \\
\hline$m i R-21$ & Equal & Equal & Yes & Higher & Equal & No & Equal & Equal & Yes \\
\hline $\operatorname{miR}-34 a$ & Higher & Equal & No & Higher & Equal & No & Equal & Equal & Yes \\
\hline$m i R-125 a-5 p$ & Equal & Equal & Yes & Lower & Equal & No & Equal & Equal & Yes \\
\hline$m i R-193 a-3 p$ & Higher & Equal & No & Higher & Equal & No & Higher & Equal & No \\
\hline
\end{tabular}

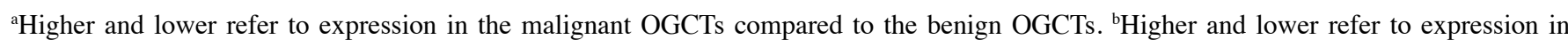
malignant or benign OGCTs as compared to SCSTs. miRNA, microRNA; OGCT, ovarian germ cell tumor; SCST, sex cord stromal tumor; sRNA seq, small RNA sequencing; RT-qPCR, reverse transcription-quantitative polymerase chain reaction.

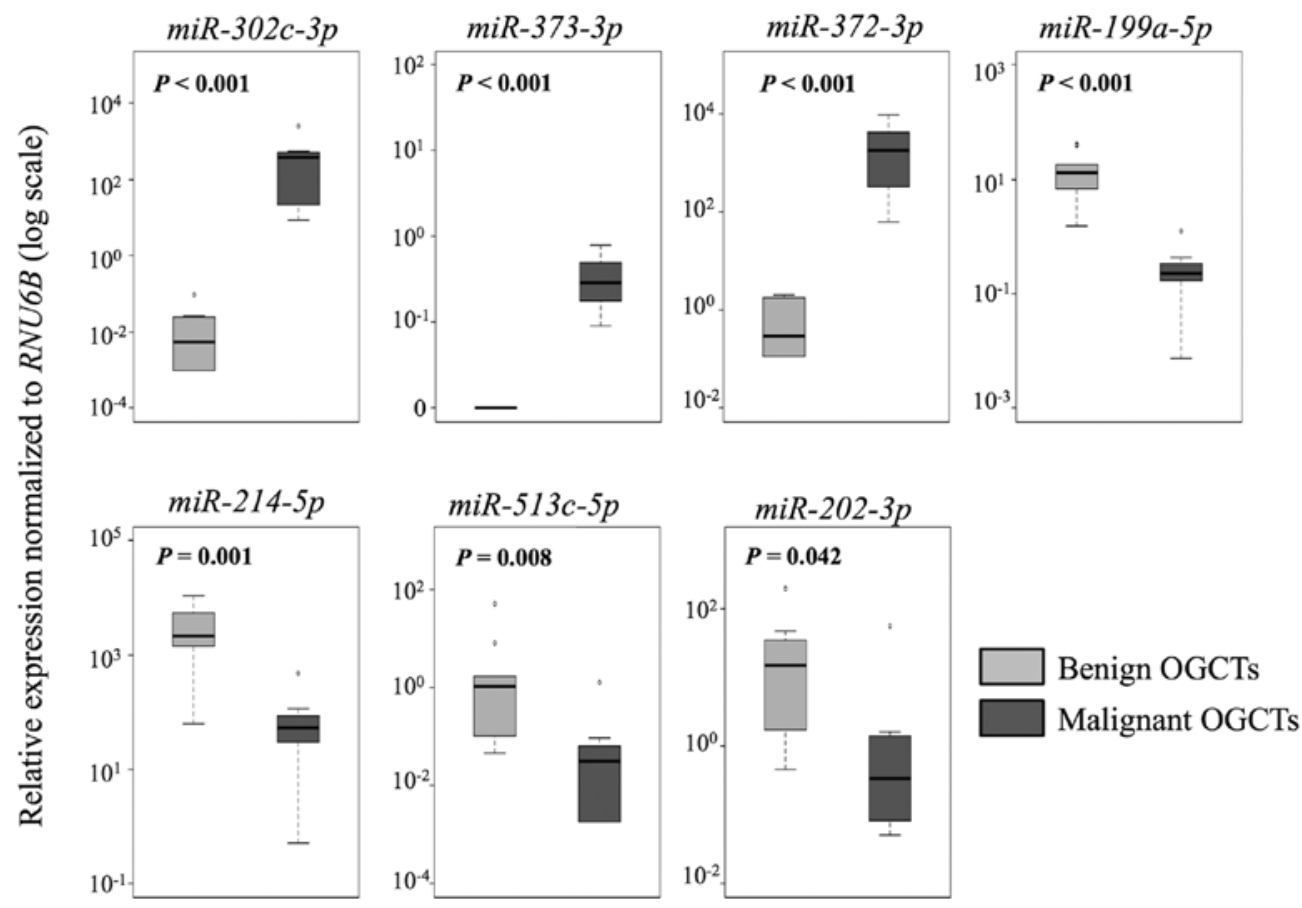

Figure 3. RT-qPCR analysis of miRNA expression in 9 benign and 7 malignant OGCTs. The boxplots show the relative expression of individual miRNAs normalized to RNU6B. P-values were calculated using the Mann-Whitney U test. $\mathrm{P}<0.05$ was considered to indicate a statistically significant difference. OGCTs, ovarian germ cell tumors; RT-qPCR, reverse transcription-quantitative polymerase chain reaction.

sequencing and the RT-qPCR results (Table III and Fig. 3). $m i R-373-3 p, m i R-372-3 p$ and $m i R-302 c-3 p$ had higher expression, whereas $m i R-199 a-5 p, m i R-214-5 p$ and $m i R-202-3 p$ had lower expression in the malignant OGCTs compared to the benign OGCTs $(\mathrm{P}<0.05$; Mann-Whitney $\mathrm{U}$ test). $m i R-21$ and $m i R-125 a-5 p$ were not differentially expressed between the two groups using both sRNA sequencing and RT-qPCR.
Similarly, 7 and 10 out of the 12 miRNAs were concordant in both methods for the comparisons between SCSTs and malignant or benign OGCTs, respectively (Table III and Figs. 4 and 5). Three miRNAs ( $m i R-372-3 p, m i R-373-3 p$ and $m i R-302 c-3 p)$ were higher and four miRNAs (miR-513c-5p, $m i R-202-3 p, m i R-199 a-5 p$ and $m i R-214-5 p$ ) were lower in the malignant OGCTs compared to the SCSTs (Fig. 4A), while 
$\mathbf{A}$
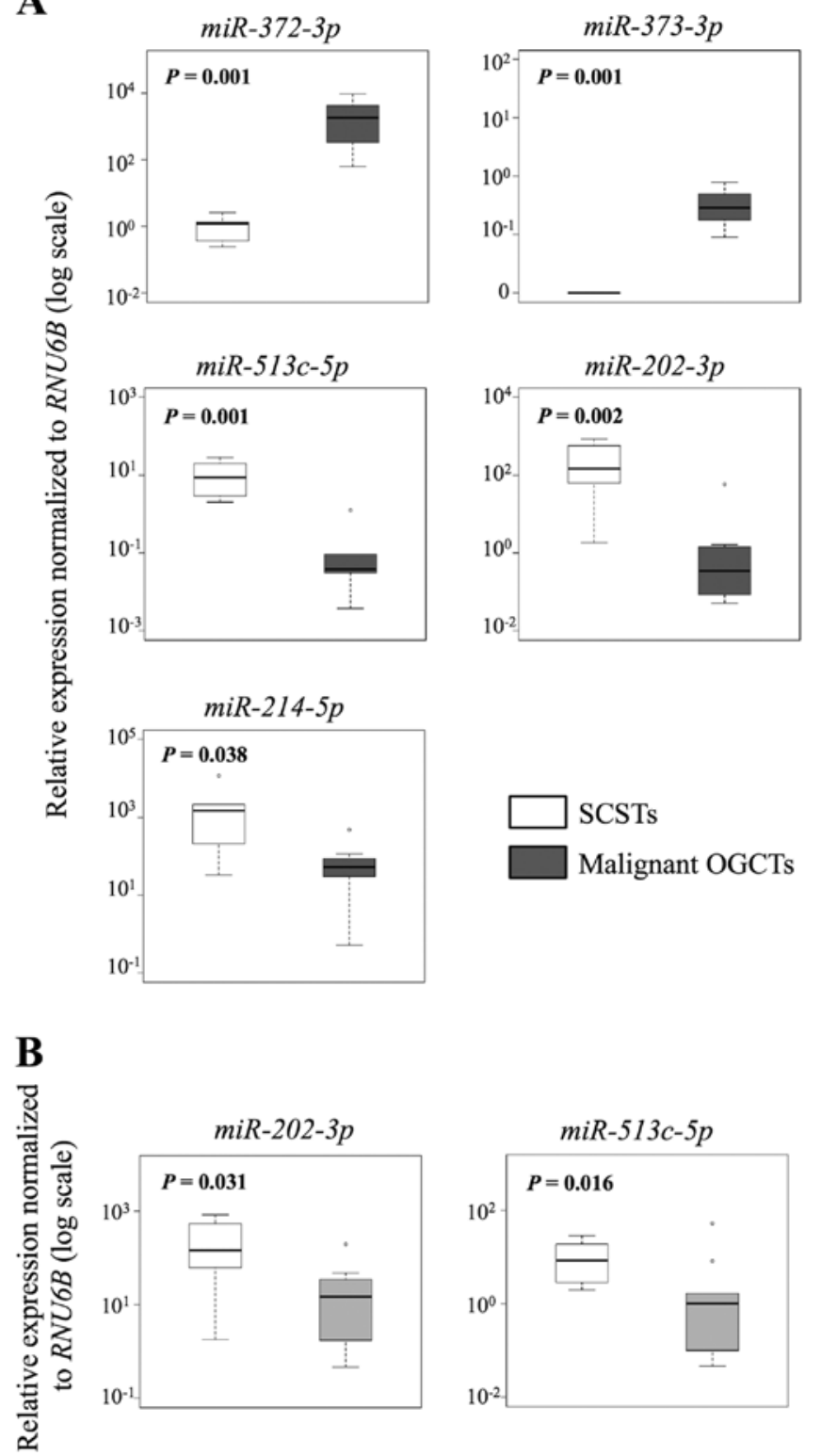
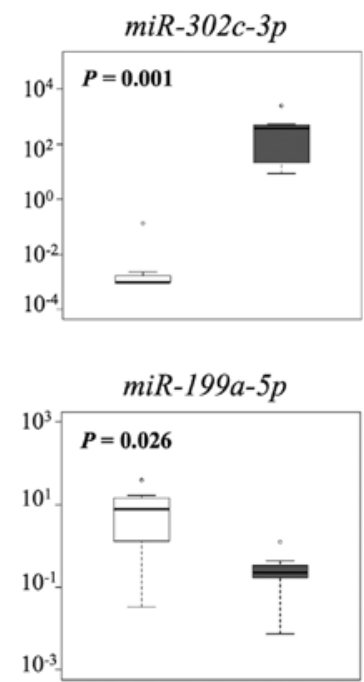

$\square$ SCSTs

$\square$ Benign OGCTs

Figure 4. Validation of differentially expressed miRNAs between 7 malignant or 9 benign OGCTs and 7 SCSTs by RT-qPCR. Boxplots illustrating the relative miRNA expression levels (A) between malignant OGCTs and SCSTs, and (B) between benign OGCTs and SCSTs. All miRNA expressions were normalized to RNU6B. P $<0.05$ was considered to indicate a statistically significant difference by Mann-Whitney U test. OGCTs, ovarian germ cell tumors; SCSTs, sex cord stromal tumors; RT-qPCR, reverse transcription-quantitative polymerase chain reaction.

only $m i R-202 c-3 p$ and $m i R-513 c-5 p$ were lower in the benign OGCTs than the SCSTs (Fig. 4B). Eight miRNAs (miR-372-3p, $m i R-373-3 p, m i R-199 a-5 p, m i R-214-5 p$, let-7f, miR-21, miR-34a and $m i R-125 a-5 p$ ) were not differentially expressed between benign OGCTs and SCSTs using both methods. Comparing the three groups, 7 miRNAs (miR-302c-3p, miR-373-3p, $m i R-372-3 p, m i R-513 c-5 p, m i R-199 a-5 p, m i R-202-3 p$ and $m i R-214-5 p)$ were significant using Kruskal-Wallis test $(\mathrm{P}<0.01$; Fig. 5), suggesting their diagnostic potential in ovarian non-epithelial tumors.

Evaluation of BECN1 expression in non-epithelial ovarian tumors. Beclin 1 (BECN1) is one of the known direct targets of miR-199a-5p $(36,37)$ and it plays an important role in germ cell survival and proliferation $(38,39)$. We therefore examined BECN1 expression in 16 OGCTs ( 7 malignant and 9 benign) and 7 SCSTs using western blot analysis. The results showed that BECN1 was the most abundant in all malignant OGCTs analyzed, moderate to high levels in SCSTs, and very low or undetectable levels in benign OGCTs (Fig. 6). For quantification, we excluded two samples, OGCT14 and OGCT11, due to low concentrations of the protein lysates. BECN1 expression was significantly different among the three groups (Kruskal-Wallis test, $\mathrm{P}<0.001)$, and the significant difference was observed in the comparison between malignant and benign OGCTs.

\section{Discussion}

miRNAs play important roles in gene regulation of many cellular processes that contribute to cancer development and progression. Despite miRNA expression and function have been characterized in a broad range of tumor types, miRNA 

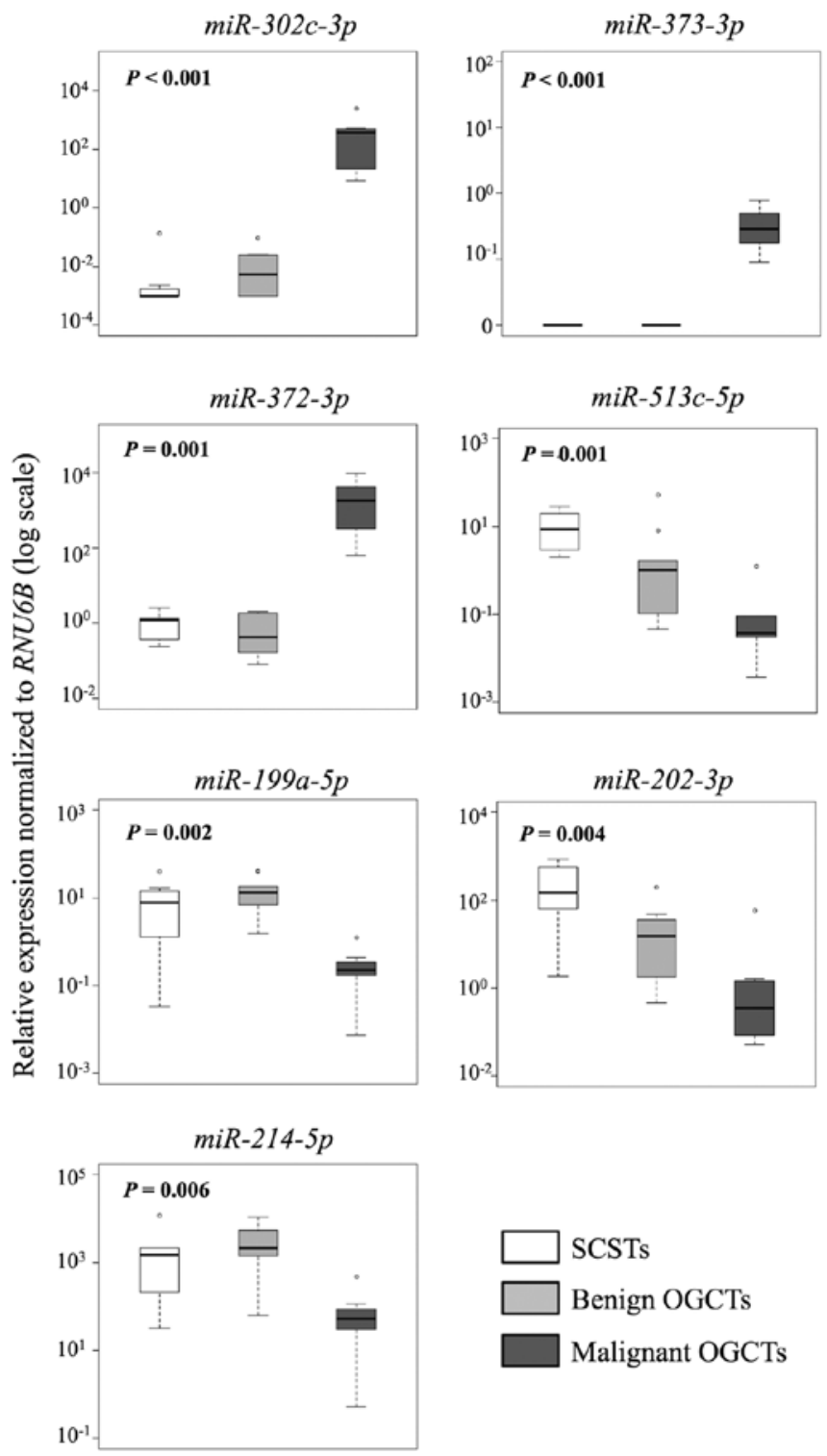

Figure 5. Significant differentially expressed miRNAs among the three non-epithelial ovarian tumor types. The boxplots show relative miRNA expression levels in 7 SCSTs, 9 benign and 7 malignant OGCTs, as determined by RT-qPCR. RNU6B was used for normalization. Statistical significance was calculated by Kruskal-Wallis test. $\mathrm{P}<0.05$ was considered to indicate a statistically significant difference. OGCTs, ovarian germ cell tumors; SCSTs, sex cord stromal tumors; RT-qPCR, reverse transcriptionquantitative polymerase chain reaction.

profiles of non-epithelial ovarian tumors are still scarce. In this study, we characterized miRNA expression pattern of OGCTs and SCSTs using sRNA sequencing. Our analysis of miRNA profiles indicated similarities and differences of expression level in these tumor types.

We observed higher expression of $m i R-302$ and $m i R-371 \sim 373$ cluster in malignant OGCTs, which is consistent with previous studies $(18-21,40)$. Although the clinical significance of these miRNAs in OGCT has not been investigated, these miRNAs appear as potential serum biomarkers for diagnosis and follow-up of malignant testicular GCTs (TGCTs) $(29,30,41,42)$. Importantly, $m i R-372$ and $m i R-373$ have been demonstrated as oncogenes in TGCTs (28), and miR-302 can regulate stemness, differentiation and tumorigenesis (43-47).
Similarly, lower expressions of $m i R-199 a$ and $m i R-214$ were also observed in malignant TGCTs $(32,48)$. $m i R-199 a-2$ (one of the two loci encoding $m i R-199 a$ ) and $m i R-214$ are derived from the same cluster located on chromosome 1q24.3, and their expressions are regulated by the same promoter and transcription factor (49). Previous studies have shown that the promoter of this locus is frequently hypermethylated in malignant testicular tumors leading to decreased expressions of $m i R-199 a$ and $m i R-214(48,50,51)$. $m i R-199 a-5 p$ has been reported to act as a tumor suppressor in TGCTs by suppressing cell proliferation, migration, invasion and metastasis, possibly through its targets podocalyxin-like $(P O D X L)$ and MAF BZIP transcription factor $\mathrm{B}(M A F B)(48,51)$. Although $m i R-214$ has been demonstrated to directly regulate proteasome $26 \mathrm{~S}$ subunit, non-ATPase 10 (PSMD10) in TGCT (32), its functional role remains undetermined. Contrary to their reduced expression in OGCTs, increased expression of $m i R-199 a$ and $m i R-214$ is found in epithelial ovarian cancer (52). $m i R-199 a$ has been shown to regulate nuclear factor $\kappa \mathrm{B}(\mathrm{NF}-\kappa \mathrm{B})$ activity via targeting inhibitor of nuclear factor $\kappa \mathrm{B}$ kinase subunit beta $(I K K \beta)(53)$, while $m i R-214$ can induce cell survival and cisplatin resistance by targeting phosphatase and tensin homolog $(P T E N)$ in ovarian carcinoma cells $(52,54)$.

Comparing with both malignant and benign OGCTs, two miRNAs ( $m i R-202-3 p$ and $m i R-513 c-5 p)$ are significantly higher in SCSTs. Expression of $m i R-202-3 p$ is detected specifically in gonads, and predominantly in the granulosa (55) and Sertoli cells (56), supporting that this miRNA is specific for SCSTs. Additionally, $m i R-202-3 p$ is tightly linked to sex hormone secretion and sex differentiation (57-59), suggesting its important role in gonadal development and differentiation. Indeed, $m i R-202-3 p$ prevents spermatogonial stem cell differentiation by suppressing multiple cell cycle regulators and RNA binding proteins (60). $m i R-202-3 p$ expression is also correlated with the expression level of testis-associated (e.g., SOX9) and ovary-associated genes (e.g., FOXL2) (57), in which both SOX9 and FOXL2 are commonly expressed in SCSTs. FOXL2 is a transcription factor required for granulosa cell differentiation and ovary development (61), and its somatic mutation has been linked to the development of adult granulosa cell tumors of the ovary (12). The mutation can protect granulosa cells from apoptosis (13) and promote tumorigenesis through enhanced glycogen synthase kinase $3 \beta$ (GSK3 $\beta$ )-mediated S33 phosphorylation (14). Further studies are yet to be conducted to determine the expression relationship between $m i R-202-3 p$ and FOXL2 and the functional role of $m i R-202-3 p$ in the development of SCST.

$m i R-513 c-5 p$ is one of the $m i R-513$ subfamily that belongs to the $m i R-506 \sim 514$ cluster. Although hardly anything is known about the functional role of $m i R-513 c-5 p$, the miRNA cluster has been demonstrated as an oncogene or a tumor suppressor depending on cellular context. In melanoma, this cluster can promote melanocyte transformation and melanoma growth (62). On the other hand, it has been shown to suppress cell growth and induce senescence in ovarian carcinoma (63), and inhibit NF- $\kappa \mathrm{B}$ pathway in TGCT (31). Notably, the miR-506 514 cluster can be induced by Forkhead box protein O1 (FOXO1) (64). FOXO1 is a transcription factor that plays important roles in regulation of apoptosis, cell cycle progression, insulin signaling and metabolic homeostasis in 

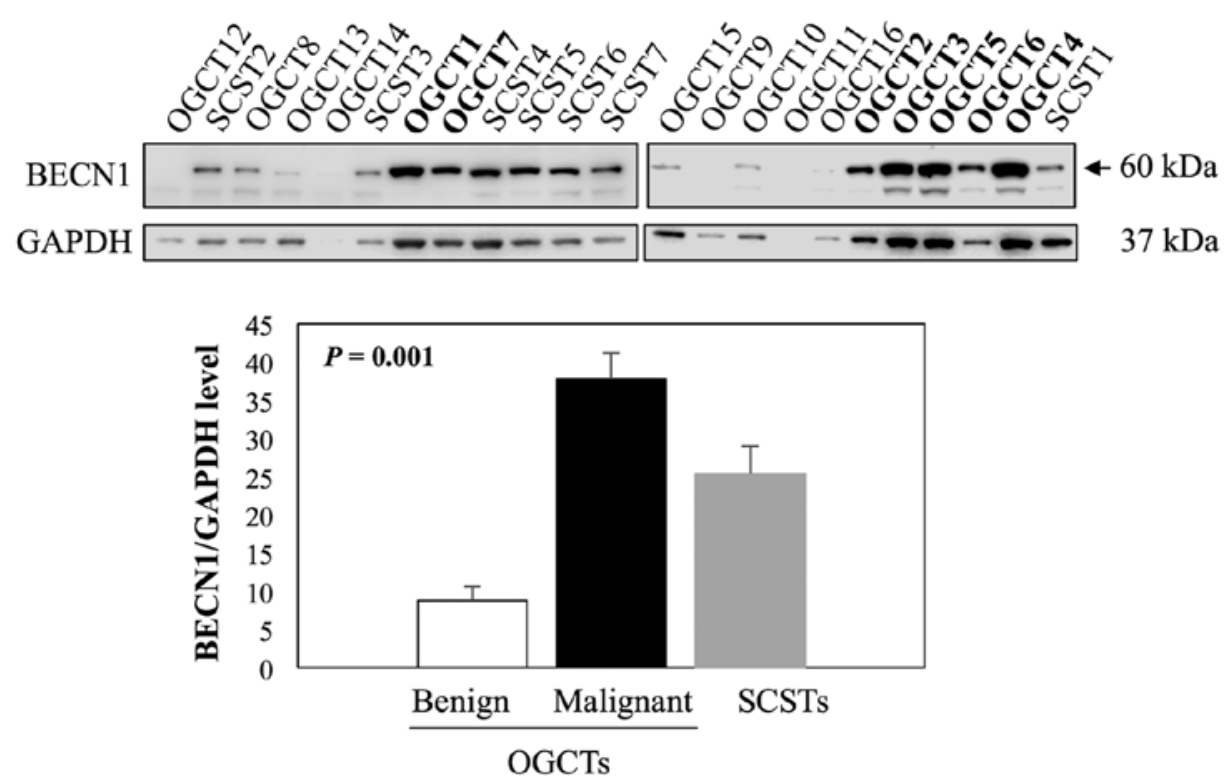

Figure 6. Evaluation of BECN1 protein expression in 7 SCSTs (SCST1-7), 9 benign (OGCT8-16) and 7 malignant OGCTs (OGCT1-7) using western blot analysis. GAPDH was used as a loading control. Bar chart represents relative mean expression with standard error of the mean. P-value was calculated using Kruskal-Wallis test. Malignant OGCTs are indicated in bold. OGCTs, ovarian germ cell tumors; SCSTs, sex cord stromal tumors; BECN1, Beclin 1.

response to oxidative stress (65). FOXO1 is expressed in granulosa cells of growing follicles (66), and is critical in granulosa cell fate decisions and follicle growth $(67,68)$. Importantly, Liu et al, showed that inactivation of the two FOX proteins FOXO1 and FOXO3 expression in mouse granulosa cells can promote ovarian granulosa cell tumor development, and coordinate PTEN depletion enhances the granulosa cell tumor occurrence in FOXOI/3 depletion mice (69). Together, it is tempting to speculate that $m i R-506 \sim 514$ cluster may contribute to the development of SCST (in particular the granulosa cell tumor subtype) through FOXO1/PTEN pathways.

We also observed increased expression of BECN1, a target of $m i R-199 a-5 p$, in malignant OGCTs, suggesting its importance in ovarian germ cell maintenance and/or tumorigenesis. In line with such speculation, BECN1 is required to control germ cell proliferation/survival $(38,39)$ and cell cycle progression $(38,70)$. BECN1 is one of the key regulators of autophagy, an evolutionally conserved regulatory pathway of cellular degradation and recycling (71). Autophagy has been shown to play important roles in germ cell function in multiple organisms, including mouse (72), fish $(73)$, worm $(74,75)$, moss (76) and sea urchin (77). Although the role of BECN1 or autophagy in human germ cell tumorigenesis remains unclear, Rossi et al demonstrated that mitogen-activated protein kinase 15 (MAPK15)-mediated autophagy can promote cell proliferation and prevent DNA damage accumulation in TGCTs (78). On the other hand, BECN1 expression is lower in malignant epithelial ovarian cancers than their non-malignant counterparts (79), and induction of autophagy in ovarian carcinoma cells can lead to tumor suppression (80). Together, autophagy may function as a tumor suppressor in ovarian epithelial tumors and an oncogene in OGCTs.

In conclusion, we showed that different non-epithelial ovarian tumors have distinct miRNA expression pattern, implying their role in tumorigenesis and their potential values as diagnostic markers. Our data also provide the starting points to elucidate the molecular mechanisms underlying the pathogenesis of these tumor types.

\section{Acknowledgements}

We thank the Cooperative Human Tissue Network for frozen tissue samples, the Stanford Sequencing Facility for sRNA sequencing and Dr Andrew Fire and the members of the sRNA group for their help and suggestions. This study was supported by Swedish Research Council, Cancer Research Funds of Radiumhemmet, Swedish Cancer Society, Karolinska Institutet and Stockholm County Council. R.K. Chang was supported by the Karolinska Institutet PhD program (KID).

\section{References}

1. Curado MP, Edwards B, Shin HR, Storm H, Ferlay J, Heanue M and Boyle P (eds.): Cancer incidence in five continents. Volume IX. IARC Sci Publ 160: 1-837, 2008.

2. Colombo N, Peiretti M and Castiglione M; ESMO Guidelines Working Group: Non-epithelial ovarian cancer: ESMO clinical recommendations for diagnosis, treatment and follow-up. Ann Oncol 20 (Suppl 4): 24-26, 2009.

3. Kraggerud SM, Hoei-Hansen CE, Alagaratnam S, Skotheim RI, Abeler VM, Rajpert-De Meyts E and Lothe RA: Molecular characteristics of malignant ovarian germ cell tumors and comparison with testicular counterparts: Implications for pathogenesis. Endocr Rev 34: 339-376, 2013.

4. Chi JG, Lee YS, Park YS and Chang KY: Fetus-in-fetu: Report of a case. Am J Clin Pathol 82: 115-119, 1984.

5. Sergi C, Ehemann V, Beedgen B, Linderkamp O and Otto HF: Huge fetal sacrococcygeal teratoma with a completely formed eye and intratumoral DNA ploidy heterogeneity. Pediatr Dev Pathol 2: 50-57, 1999.

6. Kuno N, Kadomatsu K, Nakamura M, Miwa-Fukuchi T, Hirabayashi $\mathrm{N}$ and Ishizuka T: Mature ovarian cystic teratoma with a highly differentiated homunculus: A case report. Birth Defects Res A Clin Mol Teratol 70: 40-46, 2004.

7. Arlikar JD, Mane SB, Dhende NP, Sanghavi Y, Valand AG and Butale PR: Fetus in fetu: Two case reports and review of literature. Pediatr Surg Int 25: 289-292, 2009.

8. Scully RE: Classification of human ovarian tumors. Environ Health Perspect 73: 15-25, 1987. 
9. Schultz KA, Harris AK, Schneider DT, Young RH, Brown J, Gershenson DM, Dehner LP, Hill DA, Messinger YH and Frazier AL: Ovarian sex cord-stromal tumors. J Oncol Pract 12: 940-946, 2016

10. Hoei-Hansen CE, Kraggerud SM, Abeler VM, Kaern J, Rajpert-De Meyts E and Lothe RA: Ovarian dysgerminomas are characterised by frequent KIT mutations and abundant expression of pluripotency markers. Mol Cancer 6: 12, 2007.

11. Murray MJ, Saini HK, Siegler CA, Hanning JE, Barker EM, van Dongen S, Ward DM, Raby KL, Groves IJ, Scarpini CG, et al; CCLG: LIN28 expression in malignant germ cell tumors downregulates let-7 and increases oncogene levels. Cancer Res 73: 4872-4884, 2013.

12. Shah SP, Köbel M, Senz J, Morin RD, Clarke BA, Wiegand KC, Leung G, Zayed A, Mehl E, Kalloger SE, et al: Mutation of FOXL2 in granulosa-cell tumors of the ovary. N Engl J Med 360: 2719-2729, 2009.

13. Kim JH, Yoon S, Park M, Park HO, Ko JJ, Lee K and Bae J: Differential apoptotic activities of wild-type FOXL2 and the adult-type granulosa cell tumor-associated mutant FOXL2 (C134W). Oncogene 30: 1653-1663, 2011.

14. Kim JH, Kim YH, Kim HM, Park HO, Ha NC, Kim TH, Park M, Lee $\mathrm{K}$ and Bae J: FOXL2 posttranslational modifications mediated by GSK3 $\beta$ determine the growth of granulosa cell tumours. Nat Commun 5: 2936, 2014.

15. Heravi-Moussavi A, Anglesio MS, Cheng SW, Senz J, Yang W, Prentice L, Fejes AP, Chow C, Tone A, Kalloger SE, et al: Recurrent somatic DICER1 mutations in nonepithelial ovarian cancers. N Engl J Med 366: 234-242, 2012.

16. Bushati N and Cohen SM: microRNA functions. Annu Rev Cell Dev Biol 23: 175-205, 2007.

17. Croce CM: Causes and consequences of microRNA dysregulation in cancer. Nat Rev Genet 10: 704-714, 2009.

18. Gillis AJ, Stoop HJ, Hersmus R, Oosterhuis JW, Sun Y, Chen C, Guenther S, Sherlock J, Veltman I, Baeten J, et al: High-throughput microRNAome analysis in human germ cell tumours. J Pathol 213: 319-328, 2007.

19. Palmer RD, Murray MJ, Saini HK, van Dongen S, AbreuGoodger C, Muralidhar B, Pett MR, Thornton CM, Nicholson JC, Enright AJ, et al; Children's Cancer and Leukaemia Group: Malignant germ cell tumors display common microRNA profiles resulting in global changes in expression of messenger RNA targets. Cancer Res 70: 2911-2923, 2010.

20. Murray MJ, Saini HK, van Dongen S, Palmer RD, Muralidhar B, Pett MR, Piipari M, Thornton CM, Nicholson JC, Enright AJ, et al: The two most common histological subtypes of malignant germ cell tumour are distinguished by global microRNA profiles, associated with differential transcription factor expression. Mol Cancer 9: 290, 2010.

21. Fustino N, Rakheja D, Ateek CS, Neumann JC and Amatruda JF: Bone morphogenetic protein signalling activity distinguishes histological subsets of paediatric germ cell tumours. Int J Androl 34: e218-e233, 2011.

22. Witten D, Tibshirani R, Gu SG, Fire A and Lui WO: Ultra-high throughput sequencing-based small RNA discovery and discrete statistical biomarker analysis in a collection of cervical tumours and matched controls. BMC Biol 8: 58, 2010.

23. Langmead B, Trapnell C, Pop M and Salzberg SL: Ultrafast and memory-efficient alignment of short DNA sequences to the human genome. Genome Biol 10: R25, 2009.

24. Li H, Handsaker B, Wysoker A, Fennell T, Ruan J, Homer N, Marth G, Abecasis G and Durbin R; 1000 Genome Project Data Processing Subgroup: The Sequence Alignment/Map format and SAMtools. Bioinformatics 25: 2078-2079, 2009.

25. Anders S, Pyl PT and Huber W: HTSeq - a Python framework to work with high-throughput sequencing data. Bioinformatics 31: $166-169,2015$

26. Robinson MD and Oshlack A: A scaling normalization method for differential expression analysis of RNA-seq data. Genome Biol 11: R25, 2010.

27. Love MI, Huber W and Anders S: Moderated estimation of fold change and dispersion for RNA-seq data with DESeq2. Genome Biol 15: 550, 2014

28. Voorhoeve PM, le Sage C, Schrier M, Gillis AJ, Stoop H, Nagel R, Liu YP, van Duijse J, Drost J, Griekspoor A, et al: A genetic screen implicates miRNA-372 and miRNA-373 as oncogenes in testicular germ cell tumors. Cell 124: 1169-1181, 2006.

29. Gillis AJ, Rijlaarsdam MA, Eini R, Dorssers LC, Biermann K, Murray MJ, Nicholson JC, Coleman N, Dieckmann KP, Belge G, et al: Targeted serum miRNA (TSmiR) test for diagnosis and follow-up of (testicular) germ cell cancer patients: A proof of principle. Mol Oncol 7: 1083-1092, 2013.
30. Murray MJ,Halsall DJ,Hook CE, Williams DM, Nicholson JC and Coleman N: Identification of microRNAs From the miR-371 373 and miR-302 clusters as potential serum biomarkers of malignant germ cell tumors. Am J Clin Pathol 135: 119-125, 2011.

31. Özata DM, Li X, Lee L, Liu J, Warsito D, Hajeri P, Hultman I, Fotouhi O, Marklund S, Ährlund-Richter L, et al: Loss of miR-514a-3p regulation of PEG3 activates the NF-kappa B pathway in human testicular germ cell tumors. Cell Death Dis 8 : e2759, 2017.

32. Chen BF, Suen YK, Gu S, Li L and Chan WY: A miR-199a/miR-214 self-regulatory network via PSMD10, TP53 and DNMT1 in testicular germ cell tumor. Sci Rep 4: 6413, 2014

33. Zhong X, Li N, Liang S, Huang Q, Coukos G and Zhang L: Identification of microRNAs regulating reprogramming factor LIN28 in embryonic stem cells and cancer cells. J Biol Chem 285: 41961-41971, 2010.

34. Nakano H, Yamada Y, Miyazawa T and Yoshida T: Gain-offunction microRNA screens identify miR-193a regulating proliferation and apoptosis in epithelial ovarian cancer cells. Int J Oncol 42: 1875-1882, 2013

35. Zhao Y, Li C, Wang M, Su L, Qu Y, Li J, Yu B, Yan M, Yu Y, Liu B, et al: Decrease of miR-202-3p expression, a novel tumor suppressor, in gastric cancer. PLoS One 8: e69756, 2013.

36. Yi H, Liang B, Jia J, Liang N, Xu H, Ju G, Ma S and Liu X: Differential roles of miR-199a-5p in radiation-induced autophagy in breast cancer cells. FEBS Lett 587: 436-443, 2013.

37. Li Y, Jiang W, Hu Y, Da Z, Zeng C, Tu M, Deng Z and Xiao W: MicroRNA-199a-5p inhibits cisplatin-induced drug resistance via inhibition of autophagy in osteosarcoma cells. Oncol Lett 12: 4203-4208, 2016

38. Ames K, Da Cunha DS, Gonzalez B, Konta M, Lin F, Shechter G, Starikov L, Wong S, Bülow HE and Meléndez A: A non-cellautonomous role of BEC-1/BECN1/Beclin1 in coordinating cell-cycle progression and stem cell proliferation during germline development. Curr Biol 27: 905-913, 2017.

39. Gawriluk TR, Hale AN, Flaws JA, Dillon CP, Green DR and Rucker EB III: Autophagy is a cell survival program for female germ cells in the murine ovary. Reproduction 141: 759-765, 2011.

40. Rounge TB, Furu K, Skotheim RI, Haugen TB, Grotmol T and Enerly E: Profiling of the small RNA populations in human testicular germ cell tumors shows global loss of piRNAs. Mol Cancer 14: 153, 2015.

41. Dieckmann KP, Spiekermann M, Balks T, Flor I, Löning T, Bullerdiek $J$ and Belge G: MicroRNAs miR-371-3 in serum as diagnostic tools in the management of testicular germ cell tumours. Br J Cancer 107: 1754-1760, 2012.

42. Syring I, Bartels J, Holdenrieder S, Kristiansen G, Müller SC and Ellinger J: Circulating serum miRNA (miR-367-3p, miR-371a-3p, miR-372-3p and miR-373-3p) as biomarkers in patients with testicular germ cell cancer. J Urol 193: 331-337, 2015.

43. Subramanyam D, Lamouille S, Judson RL, Liu JY, Bucay N, Derynck R and Blelloch R: Multiple targets of miR-302 and miR-372 promote reprogramming of human fibroblasts to induced pluripotent stem cells. Nat Biotechnol 29: 443-448, 2011.

44. Fareh M, Turchi L, Virolle V, Debruyne D, Almairac F, de-la-Forest Divonne S, Paquis P, Preynat-Seauve O, Krause KH, Chneiweiss H, et al: The miR 302-367 cluster drastically affects self-renewal and infiltration properties of glioma-initiating cells through CXCR4 repression and consequent disruption of the SHH-GLI-NANOG network. Cell Death Differ 19: 232-244, 2012

45. Yang CM, Chiba T, Brill B, Delis N, von Manstein V, Vafaizadeh V, Oellerich T and Groner B: Expression of the miR-302/367 cluster in glioblastoma cells suppresses tumorigenic gene expression patterns and abolishes transformation related phenotypes. Int $\mathrm{J}$ Cancer 137: 2296-2309, 2015.

46. Gu KL, Zhang Q, Yan Y, Li TT, Duan FF, Hao J, Wang XW, Shi M, Wu DR, Guo WT, et al: Pluripotency-associated miR-290/302 family of microRNAs promote the dismantling of naive pluripotency. Cell Res 26: 350-366, 2016.

47. Li HL, Wei JF, Fan LY, Wang SH, Zhu L, Li TP, Lin G, Sun Y, Sun ZJ, Ding J, et al: miR-302 regulates pluripotency, teratoma formation and differentiation in stem cells via an AKT1/OCT4dependent manner. Cell Death Dis 7: e2078, 2016.

48. Cheung HH, Davis AJ, Lee TL, Pang AL, Nagrani S, Rennert OM and Chan WY: Methylation of an intronic region regulates miR-199a in testicular tumor malignancy. Oncogene 30: 3404-3415, 2011

49. Lee YB, Bantounas I, Lee DY, Phylactou L, Caldwell MA and Uney JB: Twist-1 regulates the miR-199a/214 cluster during development. Nucleic Acids Res 37: 123-128, 2009. 
50. Cheung HH, Lee TL, Davis AJ, Taft DH, Rennert OM and Chan WY: Genome-wide DNA methylation profiling reveals novel epigenetically regulated genes and non-coding RNAs in human testicular cancer. Br J Cancer 102: 419-427, 2010.

51. Gu S, Cheung HH, Lee TL, Lu G, Poon WS and Chan WY: Molecular mechanisms of regulation and action of microRNA-199a in testicular germ cell tumor and glioblastomas. PLoS One 8: e83980, 2013.

52. Yang H, Kong W, He L, Zhao JJ, O'Donnell JD, Wang J, Wenham RM, Coppola D, Kruk PA, Nicosia SV, et al: MicroRNA expression profiling in human ovarian cancer: miR-214 induces cell survival and cisplatin resistance by targeting PTEN. Cancer Res 68: 425-433, 2008.

53. Chen R, Alvero AB, Silasi DA, Kelly MG, Fest S, Visintin I, Leiser A, Schwartz PE, Rutherford T and Mor G: Regulation of IKKbeta by miR-199a affects NF-kappaB activity in ovarian cancer cells. Oncogene 27: 4712-4723, 2008.

54. Yin G, Chen R, Alvero AB, Fu HH, Holmberg J, Glackin C, Rutherford T and Mor G: TWISTing stemness, inflammation and proliferation of epithelial ovarian cancer cells through MIR199A2/214. Oncogene 29: 3545-3553, 2010.

55. Sontakke SD, Mohammed BT, McNeilly AS and Donadeu FX: Characterization of microRNAs differentially expressed during bovine follicle development. Reproduction 148: 271-283, 2014.

56. Wainwright EN, Jorgensen JS, Kim Y, Truong V, Bagheri-Fam S, Davidson T, Svingen T, Fernandez-Valverde SL, McClelland KS, Taft RJ, et al: SOX9 regulates microRNA miR-202-5p/3p expression during mouse testis differentiation. Biol Reprod 89: 34, 2013.

57. Bannister SC, Smith CA, Roeszler KN, Doran TJ, Sinclair AH and Tizard ML: Manipulation of estrogen synthesis alters MIR202* expression in embryonic chicken gonads. Biol Reprod 85: 22-30, 2011.

58. Tao W, Sun L, Shi H, Cheng Y, Jiang D, Fu B, Conte MA, Gammerdinger WJ, Kocher TD and Wang D: Integrated analysis of miRNA and mRNA expression profiles in tilapia gonads at an early stage of sex differentiation. BMC Genomics 17: 328, 2016.

59. Bizuayehu TT, Babiak J, Norberg B, Fernandes JM, Johansen SD and Babiak I: Sex-biased miRNA expression in Atlantic halibut (Hippoglossus hippoglossus) brain and gonads. Sex Dev 6 : 257-266, 2012

60. Chen J, Cai T, Zheng C, Lin X, Wang G, Liao S, Wang X, Gan H, Zhang D, Hu X, et al: MicroRNA-202 maintains spermatogonial stem cells by inhibiting cell cycle regulators and RNA binding proteins. Nucleic Acids Res 45: 4142-4157, 2017.

61. Eggers S, Ohnesorg T and Sinclair A: Genetic regulation of mammalian gonad development. Nat Rev Endocrinol 10 673-683, 2014

62. Streicher KL, Zhu W, Lehmann KP, Georgantas RW, Morehouse CA, Brohawn P, Carrasco RA, Xiao Z, Tice DA Higgs BW, et al: A novel oncogenic role for the miRNA-506-514 cluster in initiating melanocyte transformation and promoting melanoma growth. Oncogene 31: 1558-1570, 2012.

63. Liu G, Sun Y, Ji P, Li X, Cogdell D, Yang D, Parker Kerrigan BC, Shmulevich I, Chen K, Sood AK, et al: MiR-506 suppresses proliferation and induces senescence by directly targeting the CDK4/6-FOXM1 axis in ovarian cancer. J Pathol 233: 308-318, 2014.

64. Singhal R, Bard JE, Nowak NJ, Buck MJ and Kandel ES: FOXO1 regulates expression of a microRNA cluster on $\mathrm{X}$ chromosome. Aging (Albany NY) 5: 347-356, 2013.

65. Gross DN, van den Heuvel AP and Birnbaum MJ: The role of FoxO in the regulation of metabolism. Oncogene 27: 2320-2336, 2008.
66. Richards JS, Sharma SC, Falender AE and Lo YH: Expression of FKHR, FKHRL1, and AFX genes in the rodent ovary: Evidence for regulation by IGF-I, estrogen, and the gonadotropins. Mol Endocrinol 16: 580-599, 2002.

67. Liu Z, Castrillon DH, Zhou W and Richards JS: FOXO1/3 depletion in granulosa cells alters follicle growth, death and regulation of pituitary FSH. Mol Endocrinol 27: 238-252, 2013.

68. Shen M, Liu Z, Li B, Teng Y, Zhang J, Tang Y, Sun SC and Liu H: Involvement of FoxO1 in the effects of follicle-stimulating hormone on inhibition of apoptosis in mouse granulosa cells. Cell Death Dis 5: e1475, 2014.

69. Liu Z, Ren YA, Pangas SA, Adams J, Zhou W, Castrillon DH, Wilhelm D and Richards JS: FOXO1/3 and PTEN depletion in granulosa cells promotes ovarian granulosa cell tumor development. Mol Endocrinol 29: 1006-1024, 2015.

70. You SY, Park YS, Jeon HJ, Cho DH, Jeon HB, Kim SH, Chang JW, Kim JS and Oh JS: Beclin-1 knockdown shows abscission failure but not autophagy defect during oocyte meiotic maturation. Cell Cycle 15: 1611-1619, 2016.

71. Hale AN, Ledbetter DJ, Gawriluk TR and Rucker EB III: Autophagy: Regulation and role in development. Autophagy 9: 951-972, 2013.

72. Song ZH, Yu HY, Wang P, Mao GK, Liu WX, Li MN, Wang HN, Shang YL, Liu C, Xu ZL, et al: Germ cell-specific Atg7 knockout results in primary ovarian insufficiency in female mice. Cell Death Dis 6: e1589, 2015.

73. Herpin A, Englberger E, Zehner M, Wacker R, Gessler M and Schartl M: Defective autophagy through epg5 mutation results in failure to reduce germ plasm and mitochondria. FASEB J 29: 4145-4161, 2015.

74. Zhang Y, Yan L, Zhou Z, Yang P, Tian E, Zhang K, Zhao Y, Li Z, Song B, Han J, et al: SEPA-1 mediates the specific recognition and degradation of $\mathrm{P}$ granule components by autophagy in C. elegans. Cell 136: 308-321, 2009.

75. Wang H,Lu Q, Cheng S, Wang X and Zhang H: Autophagy activity contributes to programmed cell death in Caenorhabditis elegans. Autophagy 9: 1975-1982, 2013.

76. Vera VS, Kenchappa CS, Landberg K, Bressendorff S, Schwarzbach S, Martin T, Mundy J, Petersen M, Thelander M and Sundberg E: Autophagy is required for gamete differentiation in the moss Physcomitrella patens. Autophagy: Aug 24, 2017 (Epub ahead of print). doi: 10.1080/15548627.2017.1366406.

77. Agnello M, Chiarelli R, Martino C, Bosco L and Roccheri MC: Autophagy is required for sea urchin oogenesis and early development. Zygote 24: 918-926, 2016.

78. Rossi M, Colecchia D, Ilardi G, Acunzo M, Nigita G, Sasdelli F, Celetti A, Strambi A, Staibano S, Croce CM, et al: MAPK15 upregulation promotes cell proliferation and prevents DNA damage in male germ cell tumors. Oncotarget 7: 20981-20998, 2016.

79. Shen Y, Li DD, Wang LL, Deng R and Zhu XF: Decreased expression of autophagy-related proteins in malignant epithelial ovarian cancer. Autophagy 4: 1067-1068, 2008.

80. Kandala PK and Srivastava SK: Regulation of macroautophagy in ovarian cancer cells in vitro and in vivo by controlling glucose regulatory protein 78 and AMPK. Oncotarget 3: 435-449, 2012.

This work is licensed under a Creative Commons Attribution-NonCommercial-NoDerivatives 4.0 International (CC BY-NC-ND 4.0) License. 